\title{
On measures to stimulate the development of settlements of the Arctic zone of the Republic of Sakha (Yakutia)
}

\author{
Mikhail Tarasov ${ }^{1}$, Marianna Teryutina ${ }^{1}$, Olesya $\mathrm{Val}^{1,{ }^{1},}$, and A. Danilova ${ }^{2}$ \\ ${ }^{1}$ Yakut State Agricultural Academy, 677013, 23, 4/56 Kalandarashvili str., Yakutsk, Russia \\ ${ }^{2}$ Russian State Agrarian University - Moscow Timiryazev Agricultural Academy, 127550, 49 \\ Timiryazevskaya str., Moscow, Russia
}

\begin{abstract}
The article describes how in extreme, harsh natural and climatic conditions of the Arctic, such activities as cattle breeding, horse breeding, reindeer husbandry, hunting, and fishing are conducted. Effective development of northern settlements, active construction and operation of inter-district highways are reviewed and justified. Attention is drawn to the acute problem of training, retraining, and securing qualified specialists in the North, providing them with housing. It is recommended to develop proposals on the issues of credit and financial and tax policy, logistics, which are related to the northern state policy, as well as targeted control over the timing of the transfer and targeted funds for the purpose and their use. The goal is to justify measures to stimulate the development of settlements of the Arctic zone of the Republic of Sakha (Yakutia). Methodology: the study of existing regulations and their retrospective analysis. Results: Reasonable proposals for stimulating the development of the settlements.
\end{abstract}

It is known that Yakutia is the largest region of the Arctic zone of the Russian Federation. The Arctic regions (uluses) in the Republic have a total area of $1,701,100 \mathrm{~km}^{2}$, and the resident population is only 70,000 people in 121 settlements. The distance from settlements to the district center is $200 \mathrm{~km}$ on average with the worst transport infrastructure [6].

And in these very extreme, severe natural and climatic (and uncomfortable) conditions of life in the Arctic, cattle breeding, horse breeding, reindeer husbandry, hunting and fishing are conducted. In the nine months of the harsh winter, the northern people are struggling to survive.

In these conditions, the most important task for the further effective development of northern settlements in the context of municipal reform is the improvement of the system of rational settlement of rural residents, which provides (a) the development of all northern settlements regardless of the type and population, (b) the creation of an enabling habitat, settlements serving as service centers for a group of populated areas, ensuring the interrelation of northern settlements with each other and with district (ulus) centers in order to overcome the isolation of rural communities in the long-term.

\footnotetext{
*Corresponding author: olesya-val@ mail.ru
} 
There is no way to do without active construction of inter-regional ulus roads. Foreign and domestic experiences in the construction and operation of roads on permafrost in the conditions of tundra and forest-tundra are available. The heads of the Arctic regional and municipal entities have to create a joint fund for the Arctic Ulus Foundation with a contribution of $2-3 \%$ of the district budgets to solve the problem being related to the construction of the overland all-the-year-round transport communications. Moreover, the northern Arctic regions (uluses) receive subsidies and subventions on the zones of accommodation of northern settlements. For example, (1) reindeer-breeding: Zhigansky, Allaikhovsky, Nizhnekolymsky; (2) reindeer herding and industrial reindeer herding: Anabar, Olenek, Bulun, Ust-Yansky; (3) animal-breeding/reindeer-breeding: Abyisk, EvenBytantaisky, Srednekolymsky; (4) animal-breeding/reindeer-breeding with focal agriculture: Momsky, Verkhnekolymsky uluses.

On the other hand, such an approach as a whole contributes to the Government of the Republic of Sakha (Yakutia) to adjust the formation of local budgets of settlements by means of equalizing the socio-economic development of settlements in unequal economic conditions and through state regulation, i.e. an increase in subsidies and subventions in the zones engaged in agricultural production and traditional northern branches of agriculture. Since in many rural settlements of the northern ulus, it is precisely the traditional northern industries that are the basis for the way and socio-economic status of the local indigenous population.

The state financial support is also badly needed for surveying and land management of reindeer pastures of nomadic tribal communities of the Arctic regions (uluses), which will lead to the strengthening of the material and technical base of farms, improvement of the forage base, and the creation of attractive production and nomadic conditions. All these measures naturally fit into the state strategy of social and economic development of the northern territories in the places of compact residence of the indigenous population in the conditions of municipal reform, which is based on the principles of "preserving the historically established traditional bases for the development of northern territories," the development of settlements as a single socio-economic, natural, and cultural-historical complex, which performs industrial, socio-demographic, cultural, nature conservation and recreational functions.

Today, the goal-oriented implementation of training, retraining, and placement of local indigenous personnel in managerial, national, and regional policy in accordance with the needs of the municipal formations of the northern (arctic) districts (uluses) is more than ever an acute problem. For this, it is necessary to create all conditions for the revival and development of national and nomadic schools, upbringing and education in their native language. At the same time, it is necessary to help those wishing to learn the languages of Sakha and the small peoples of the North inhabiting these territories. The provision of young specialists with all the conditions of life support and vital activity remains urgent. Since the current socio-economic situation of northern villages and settlements as a whole is characterized by low standards of living and the worsening demographic situation. Very modest are the size of incomes in relation to the established prices for high-grade food and comfortable living of a person in such severe conditions of the North. And it is simply necessary in such conditions.

Against the backdrop of a low level of food security and fuel and energy resources, a poorly developed service sector, the population is discontented with the budgetary security of their settlement. At the same time, stable provision of consumer goods to the population of the Arctic regions is possible with timely financing of the early delivery of food in full, taking into account extremely short terms and the adoption of a unified system of state support for the provision of consumer goods to the population and institutions of the national sphere. Compensation of transportation costs for inter-district and intra-district 
food supplies would help to equalize the imbalances that arise when delivering goods and supplying foodstuffs to the population through allocations of funds to the uluses' budget of according to the standards determined depending on the number of people living in the region. It would be desirable, from our point of view, to revive all forms of trading stations (cooperative relations) for the modern organization of the purchase, storage, processing, sale of reindeer breeding and fishing products, as well as the effective provision of commodity exchange between the populations of the northern settlements and the structural subdivisions of the system of factories. Its revival needs state support.

In our opinion, it is also necessary for the Government of the Republic of Sakha (Yakutia) to find alternative sources of energy and to minimize the whole complex of costs associated with the energy supply of the North's legacy. Otherwise, the intensive disposal of fixed assets from the economic turnover of northern enterprises (organizations) and the reduction of biological resources could lead to the fact that there would be no time to plan at the level of local self-government of the Northern regions.

Based on the accumulated experience of state management, executive authorities and municipalities need to work together to develop proposals on issues of credit-financial and tax policy, logistics being related to the northern state policy, as well as targeted control over the timing of the transfer of targeted funds for the purpose and their use.

The main branch of the Arctic, along with others, is fishing, the state of which is deteriorating year after year, and its inertial development leads to an aggravation of existing problems.

The key mechanism is the removal of administrative barriers to fishing by reducing government institutions that oversee the industry. Maintaining state support at the same level as today will lead to a gradual reduction in catch volumes and a predominance in processing of imported products. In light of low volumes of catch but greater demand for products, it would reduce the percentage of production of local raw materials, contributing to deterioration of the industry and increasing the outflow of young people from the northern and arctic regions (uluses).

In conclusion, we would like to note that in order to implement everything that is said in this article, it is necessary to develop normative legal acts and to adopt them both at the regional and federal levels. The Arctic and the North require large investments, since the development of the Arctic is topical and relevant, and it's high time to move from words to realizing practical cases [6].

\section{References}

1. Government of the Republic of Sakha (Yakutia), Law of the Republic of Sakha (Yakutia) No 179-1 of June 25, 1997 on Reindeer Herding (Yakutsk, 1997)

2. Government of the Republic of Sakha (Yakutia), Law of the Republic of Sakha (Yakutia) No. 991-III of July 11, 2007 on the State Target Program "Socio-economic $d$

Development of the Village of the Republic of Sakha (Yakutia) for 2007-2011" (Yakutsk, 2007)

3. Government of the Russian Federation, Decree No. 717 of July 14, 2012 on the State Program for the Development of Agriculture and Regulation of the Markets of Agricultural Products, Raw Materials, and Food for 2013-2020 (Moscow, 2012)

4. Government of the Russian Federation, State Program for the Development of Agriculture and Regulation of Markets for Agricultural Products, Raw Materials, and Food for 2013-2020 (Moscow, 2012) 
5. Government of the Russian Federation, The Federal Target Program on Sustainable Development of Rural Areas for 2014-2017 and for the period to 2020 (Moscow, 2013)

6. V. I. Kondratieva, The Arctic: Perspectives of sustainable development: a collection of reports of the participants of the International Scientific and Practical Conference (Yakutsk, November 26-28, 2014) (Yakutsk, Center for Strategic Studies of the Republic of Sakha (Yakutia), 2015)

7. Collection of abstracts: the Arctic - perspectives for sustainable development (Yakutsk, 2014) 